\title{
11 The Evolving Role of Agriculture in Ethiopia's Economic Development
}

\author{
PAUL DOROSH
}

Ethiopia is changing at an accelerating pace. Major investments in roads are bringing tens of millions of people effectively closer to major urban centers and services. Expansion of telecommunications, especially through cellular phones, likewise has connected much of the country and vastly improved the spread of information. The average electricity generation capacity during 1990-99 was 334 megawatts, and by 2010 that capacity had more than quadrupled, to 1,498 megawatts. During the same period, the capacity per capita almost tripled (from 6.0 watts to 17.4 watts). These advances are providing new opportunities for industrial production and modern services.

These changes are remarkable, particularly given Ethiopia's history as a country of widespread poverty, exacerbated by severe droughts and major famines in the 1970s and 1980s. In the past two decades, public investments in agricultural development and the provision of safety nets have dramatically increased food security. Although there remains some debate over the size of cereal production increases, there is strong evidence to suggest that food production has indeed increased substantially, particularly in the 2000s, and that food security has improved at both the national and the household levels. Official production figures indicate that there was an average annual growth rate of 12 percent in cereal production between 2004/05 and 2007/08. ${ }^{1}$ Average per capita incomes rose from \$131.7 in 2001 to \$200.7 in 2009 (World Bank 2010). ${ }^{2}$ Malnutrition estimates in the mid-2000s showed a substantial decline in child mortality.

The lack of nationally representative household data between 2005 and 2010 made it impossible to provide conclusive estimates of poverty and food insecurity when Ethiopia's new five-year Growth and Transformation Plan was

1. As noted in Chapter 1, many observers, including Dercon, Hill, and Zeitlin (2009), have questioned the high growth rates in these official estimates because of the relatively slow pace of adoption of improved seed varieties, the minimal expansion of irrigated area, and the apparent scarcity of land in the Ethiopian highlands, among other factors.

2. Gross domestic product per capita is measured in constant (2000) US dollars. 
developed in 2010. Nonetheless, the apparent success of Ethiopia's agricultural and overall economic growth strategies prompted a major shift in development strategy, one involving a lesser role for agriculture and a much greater emphasis on industry and services for generating growth and poverty reduction.

\section{From the Agricultural Development-Led Industrialization Strategy to Growth and Transformation}

Beginning in the late 1990s, Ethiopia emphasized agricultural growth as the centerpiece of its Agricultural Development-Led Industrialization (ADLI) strategy. This represented a radical shift in policy from an "industry-first" approach adopted by the Derg regime to an "agriculture-first" policy, with a particular focus on peasant agriculture. Under ADLI, agricultural growth was expected to spur industrialization through backward and forward growth linkages (creation of demand for inputs, processing of agricultural outputs, and increased household demand for consumer goods). Moreover, agricultural development would be part of a broader rural development strategy including rural infrastructure development, expansion of education, and improved health services. ADLI thus provided the guiding framework for Ethiopia's development strategy in the 2000s, as outlined in the Sustainable Development and Poverty Reduction Program that was in place from 2002/03 to 2004/05 and the Plan for Accelerated and Sustained Development to End Poverty that was implemented from 2005/06 to 2009/10 (Table 11.1 and Box 11.1).

To a large extent, it appears that the ADLI strategy has succeeded. However, continued reliance on agriculture as a major driver of economic growth is increasingly seen as problematic, for three reasons. First, there are serious concerns about the prospects for continued growth in agriculture. Land and water resource constraints in the highlands and the drought-prone areas will make it

TABLE 11.1 Average sectoral growth rates under the Plan for Accelerated and Sustained Development to End Poverty (PASDEP) and the Growth and Transformation Plan (GTP), 2005/06-2014/15 (percent)

\begin{tabular}{lccr}
\hline Plan (scenario/result) & Agriculture & Industry & Service \\
\hline & & $2005 / 06-2009 / 10$ & \\
PASDEP base & 6.0 & 11.0 & 7.0 \\
PASDEP high & 6.4 & 18.0 & 10.3 \\
PASDEP achieved & 8.4 & 10.0 & 14.6 \\
& & $2011 / 12-2014 / 15$ & \\
GTP base & 8.6 & 20.0 & 10.6 \\
GTP high & 14.9 & 21.3 & 12.8 \\
\hline
\end{tabular}

SOURCE: Ethiopia, MoFED (2006, 2010). 


\section{BOX 11.1 Ethiopia's Growth and Transformation Plan, 2010/11-2014/15}

- The Growth and Transformation Plan (GTP) is the latest macrodevelopment agenda developed by the Government of Ethiopia. It succeeds the Plan for Accelerated and Sustained Development to End Poverty (PASDEP) and will be effective from 2010/11 to 2014/15.

- The GTP concentrates on a locally driven economy and targets an economic growth rate of 14.9 percent. This growth target is higher than that in the PASDEP.

- The GTP maintains agriculture as a major source of economic growth, but it aims to create favorable conditions for the industry to play a key role in the economy.

- The GTP provides for investment in the expansion of infrastructure development (roads, electricity production, railway lines, and telephone infrastructure).

- The second Road Sector Development Program (2011/12-2014/15) seeks to achieve the following objectives by the end of the plan period:

$\circ$ reduce the average time to reach the nearest all-weather road from its current 3.7 hours to 1.2 hours,

- reduce areas that are located farther than 5 kilometers from all-weather roads to 29 percent from their present 64 percent, and

- connect all kebele in the country to nearby all-weather roads.

- By using modern technologies and local resources and mobilizing public-private partnerships, the GTP aims to expand the country's rail network. Some 2,000 kilometers of rail network will be under construction during the plan period.

- The GTP focuses on energy policy in terms of expanding the coverage and production of electricity; it aims to increase power generation to 10,000 megawatts by 2015 , covering 75 percent of the country. The plan also aims to enhance Ethiopia's biofuel capacity.

- The telecommunications strategy in the GTP emphasizes upgrading the network already built to accommodate emerging latest information technologies and expanding fixed-line and mobile telephone services and Internet services.

- The GTP makes provision for significant expansion of irrigation and road, air, and maritime transportation capacities.

- Educational policy in the GTP is captured under the Education Sector Development Program, and it will focus on expanding functional adult literacy, providing Technical and Vocational Education and Training, and expanding higher education services.

- Improving access to and the quality of healthcare is a major component of the GTP's Health Extension Program. Reductions in maternal mortality, infant mortality, and the prevalence of malaria, as well as increases in immunization and tuberculosis detection rates, are some of the key objectives of the plan.

SOURCE: Author's compilation based on Ethiopia, MoFED (2010). 
increasingly difficult to achieve high output growth rates in these areas, though major investments in irrigation and expansion of cultivation in rainfall-sufficient areas outside of the highlands (such as Benishangul-Gumuz and Gambella regions in western Ethiopia) may enable sizable gains in agricultural production in these regions.

Second, without continued (and even accelerated) growth in nonagriculture sectors, there would likely be insufficient demand for agricultural products. In general, consumption demand for major agricultural staples (particularly cereals) is income inelastic; that is, growth in household incomes generates a less than proportionate increase in demand (Chapter 7). Moreover, as incomes rise, the income elasticity of demand (the percentage of change in quantity demanded by a 1 percent increase in income) can be expected to fall. Thus, as Ethiopia's per capita income rises, further increases will generate even smaller increases in households' demand for key agricultural products. As a result, supply will increase faster than demand, and real prices of cereals will fall. ${ }^{3}$ The simulation analysis in Chapter 8 shows that, even with growth in agricultural production of 6 percent per year, a moderately higher rate of growth in nonagricultural sectors of 8 percent per year is sufficient to generate enough demand to keep real prices for agricultural products relatively stable (real prices of teff and sorghum will be nearly constant; those of wheat and maize will fall by about 1 percent per year). More rapid growth in agriculture relative to industry and services, however, will likely result in steeper declines in real agricultural prices, reducing rural welfare and slowing overall growth as it discourages input use and productivity growth in agriculture.

Third, related to normal shifts in demand patterns as per capita incomes rise, economic growth almost always requires a structural transformation of the economy, from agriculture to industry and services. This shift in economic output is typically accompanied by growing urbanization, in part due to increases in productivity that occur due to agglomeration - clustering of firms, households, and workers that can enable larger and more efficient labor and product markets, as well as sharing of information and technologies. If Ethiopia follows this typical path of economic development, it will lead to even more rapid growth in industry and services and in the public and private investments needed to make this growth possible. Nonetheless, rapid agricultural growth remains necessary to achieve a rapid rise in living standards in Ethiopia, both in order to keep real food prices from rising excessively as incomes grow and

3. Rapid overall (macroeconomic) inflation, as experienced in Ethiopia from 2007 to 2009 , resulted in gains in the nominal (actual) prices of almost all commodities. Adjusting for overall inflation by expressing prices in real terms (for example, by dividing prices by a general price index, such as the consumer price index) gives a better indication of changes in incentives for production and consumption, as well as the extent to which supply is increasing more rapidly or slowly than demand. 
to avoid the rise in rural poverty that could result from stagnation in the incomes of low-income rural households.

\section{Major Challenges for Agricultural and Food Policy}

To achieve high economic growth rates, reduce poverty, and enhance household food security in the coming decade, agricultural and food policy in Ethiopia must address five major challenges: sustaining growth in crop and livestock production, increasing market efficiency, providing effective safety nets, maintaining macroeconomic incentives and stability, and managing the rural-urban transformation.

\section{Sustaining Growth in Crop and Livestock Production}

Although Ethiopia successfully increased its crop production (especially for cereals) in the first decade of the 2000s, further increases will by no means be automatic. As noted earlier, increasingly binding land and water constraints will make it increasingly difficult to achieve production gains of both crops and livestock in the highlands without major investments in productivity-increasing technologies (including improved seeds and veterinary services, extension, and small-scale irrigation). ${ }^{4}$ Current investment plans for the highlands (as outlined in the Agricultural Growth Programme) place a major focus on higher-potential areas where rainfall is generally sufficient for crop cultivation and there is sufficient forage. To achieve production gains, however, problems in seed multiplication and distribution must be overcome (Chapter 3). Likewise, the use of chemical fertilizers will likely have to increase. Ultimately, this may require a greater role for the private sector, allowing private traders to compete fairly with the agricultural cooperatives (Mellor and Dorosh 2010).

Prospects for the drought-prone areas are far less promising; there, promotion of nonfarm activities in rural areas and vibrant small cities may provide the most viable alternative for increasing food security (as is discussed later). Production from newly cultivated lands in rainfall-sufficient areas outside the highlands offers some prospect of national production gains, but infrastructure and marketing constraints must be overcome, and great care will be required to avoid environmental degradation.

\section{Increasing Market Efficiency}

Domestic markets for agricultural commodities have grown exponentially over the past two decades, resulting in increased competition, reduced seasonality,

4. Concerns about the implications for future agricultural growth of land constraints in the Ethiopian highlands have been noted by various analysts of Ethiopian agriculture, including the World Bank (2006) and Dercon, Hill, and Zeitlin (2009). Even if the official data on area expansion in the second half of the first decade of the 2000s are accurate, there is good reason to expect increasingly binding land shortages in the coming decade. 
and the spatial integration of markets (Chapter 5). Gains in per capita incomes have generated increased effective demand for basic staples, as well as for animal products. Growth of cities has meant that much of this increase in demand is met from market purchases rather than from farmers' own consumption. Improvements in roads and the expansion of telecommunications have enabled more rapid transport of goods and almost instantaneous communication of market information.

Nonetheless, private markets continue to be viewed with suspicion by many in Ethiopia, and episodes of high and rising prices (such as in 2008 and 2011) are met by calls for restrictions on private trader price margins and stocks. At the same time, Ethiopia has created the Ethiopian Commodity Exchange, the largest commodity exchange in Sub-Saharan Africa outside of the Republic of South Africa. Since late 2008, contracts for almost all of Ethiopia's coffee exports have gone through this exchange. Yet a period of slow movement of coffee exports in late 2009 led to seizure of private trader stocks.

Thus, the role of private-sector trade in Ethiopia's agriculture remains, to a large extent, in a state of flux. There is reason for concern about the concentration of market power for internationally traded commodities, particularly given the country's reliance on only one port (Djibouti) and the difficult logistics of transport, handling, and storage involved in international trade. Promoting competition in these markets and paying attention to growing bottlenecks are crucial for market efficiency. Yet without vibrant, competitive private-sector trading, it will be extremely difficult for Ethiopia's export trade (and import trade in fertilizer and other key commodities) to prosper.

Similarly, in domestic markets, in most of Asia successful agricultural development has involved major roles for the private sector, even where governments have intervened to stabilize prices (Ahmed, Haggblade, and Chowdhury 2000; Rashid, Gulati, and Cummings 2008; Dorosh 2009). The implication for Ethiopia is that it is possible for competitive private markets in agricultural inputs and outputs to coexist with cooperatives (Mellor and Dorosh 2010). Early evidence on the effects of cooperatives suggests, however, that their impact on farmer output prices and incomes was small (Bernard et al. 2010).

\section{Providing Effective Safety Nets}

For decades Ethiopia relied on food aid both to increase the supply of food (especially after major crop production shortfalls) and to use for direct transfers to poor households. The shift to the Productive Safety Net Programme (PSNP) in 2005 as a means to provide a consistent and less ad hoc means of addressing chronic poverty and food insecurity was a major step in the design of an overall social protection program.

Given the high levels of poverty in Ethiopia, large-scale safety nets are likely to be an essential part of poverty alleviation programs. The PSNP has proven to be very successful, at least in terms of effectively targeting poor households with cash and food transfers (Chapter 10). Initial efforts to supple- 
ment these transfers through the Other Food Security Program also have had at least moderate success, but links to credit, skills training, and other programs to build household assets and sustainable livelihoods should be strengthened if PSNP participant households are to escape poverty (Gilligan, Hoddinott, and Taffesse 2009). In the medium term, effective safety nets for urban areas will likely be needed as well. These programs need not involve food transfers. Nonetheless, they can still make a major contribution to urban food security through increases in households' access to food.

Emergency food aid will continue to be required to address major production shortfalls. Much progress has been made in improving information flows and building national and regional capacity for monitoring emerging food insecurity problems. Nevertheless, strengthening a decentralized response system (via joint government and international organizational planning and regional logistics arrangements) will remain important to improve the timeliness of responses to serious hunger threats before they evolve into dire famine conditions.

Food aid need not provide the only or even the dominant means of increasing the supply of food in times of production shortfalls, however. Instead, private imports can make a major contribution to the stability of supplies, provided that government policy on the timing and levels of food aid inflows and distribution is transparent (Cody, Dorosh, and Minten 2009; Dorosh, Dradri, and Haggblade 2009).

\section{Maintaining Macroeconomic Incentives and Stability}

Macroeconomic instability, as reflected by high rates of domestic inflation (2007-09) and foreign exchange shortages (2009-10), had detrimental effects on agriculture and food security, as well as on the overall economy. High rates of domestic inflation, including rapid increases in the price of major staples, led to serious declines in real incomes and access to food, particularly for households relying on fixed or slowly adjusting salaries in urban areas. Foreign exchange shortages led to the rationing of foreign exchange and the inability of the private sector to import wheat (and thereby add to the total domestic supply and reduce domestic prices) when it would have been profitable to do so (Ahmed and Dorosh 2009). Foreign exchange rationing, put into place in lieu of a nominal and real exchange rate depreciation that would have brought supply and demand for foreign exchange more closely into balance, also reduced incentives for the production of tradable goods (including export crops such as coffee and sesame) and lowered the real incomes of most households (Dorosh, Robinson, and Ahmed 2009).

With the September 2010 devaluation of the Ethiopian birr, there was no longer a need for rationing, removing the major distortion in the foreign exchange market and Ethiopia's overall economy. Moreover, macroeconomic inflation already had been brought under control by late 2009 through sharp restrictions on domestic credit and other fiscal and monetary measures. Achieving and 
sustaining macroeconomic stability through judicious macroeconomic policies will be crucial to the success of Ethiopia's growth and poverty reduction efforts.

\section{Managing the Rural-Urban Transformation}

Ethiopia's spatial transformation has only just begun. Ethiopia remains one of the least urbanized countries in the world (with 16 percent urbanization, by official CSA estimates [see Table 2.9, p. 41], compared to an average of 30 percent in Sub-Sahara Africa). Measuring urbanization in terms of spatial agglomerations of people in and near cities of 50,000 or more shows that urbanization growth rates between the population census years 1984 and 2007 were much higher (between 8 and 9 percent) than estimates based on official definitions of urban (4.2 percent) (Dorosh et al. 2011).

One reason for the slow pace of urbanization in the past is that government policy has been designed to slow rural-urban migration through regulations prohibiting the sale of land, proscribing the loss of land rights for those who leave rural areas, and imposing registration requirements for new migrants. In the coming decade, allocation of public investments across sectors and between rural and urban areas, land policies, and various regulations on labor mobility will all likely be major determinants of economic growth and poverty reduction in Ethiopia.

There is some evidence suggesting that investments in increasing agricultural productivity, particularly in favorable agroecological environments and in a context of industrial productivity growth at rates similar to those in 2005-09, will provide the best pathway for overall reductions in poverty in Ethiopia (Dorosh et al. 2011). Moreover, removing the existing constraints to internal migration may speed the spatial and structural transformation of Ethiopia, promoting economic growth and urban industrial development. Much further analysis is needed, however, to support government policy regarding the appropriate balance of public investments to promote agricultural growth while providing enough urban infrastructure and services to prevent a rise in costs due to urban congestion.

\section{Conclusions}

Ethiopia has made enormous progress since the famines of the 1970s and 1980s. Widespread economic growth, food production increases, massive increases in infrastructure, improvements in telecommunications, more vibrant agricultural markets, and a well-functioning safety net are major achievements. The challenge now is to build on these successes and to accelerate development so as to maintain rapid overall growth and to sharply reduce poverty in both rural and urban areas.

Research and analysis related to the agricultural sector and food security can play an important role in facilitating effective policymaking and promoting 
growth and poverty reduction objectives. This will entail not only the work of research and analysis itself but the wide dissemination of data and materials, strengthening of the capacity of both individuals and key institutions (government agencies, universities and research organizations), and open dialogue and debate on policy design and impacts.

Food security in Ethiopia is likely to be a challenge for decades given the country's susceptibility to major droughts and other shocks. Successful policy will mean not only the avoidance of large-scale famines if and when major production shortfalls occur but also sustained improvements in food availability, access, and nutrition at the national and household levels.

The untimely death of Prime Minister Meles Zenawi in August 2012 was a profound shock to the country. Meles had led Ethiopia and its development efforts for over two decades, making key decisions through his active involvement in policy making. As of April 2013, the political transition has been smooth, with Deputy Prime Minister Hailemariam Desalegn formally named Prime Minister in September 2012.

How these developments will influence Ethiopia's policies and development remains to be seen. Macro-economic stability continues to be a major challenge and the debate over the relative emphasis on agriculture versus industry and rural versus urban in the country's development strategy may intensify. In this debate, it is hoped that the lessons of Ethiopia's successes in food and agriculture under the Meles regime outlined in this book may inform policies and investments that promote broad-based growth that improves the welfare of Ethiopia's rural and urban poor.

\section{References}

Ahmed, H., and P. Dorosh. 2009. Foreign Exchange Rationing, Wheat Markets, and Food Security in Ethiopia. Ethiopia Strategy Support Program 2 Discussion Paper 004. Washington, DC: International Food Policy Research Institute.

Ahmed, R., S. Haggblade, and T. E. Chowdhury, eds. 2000. Out of the Shadow of Famine: Evolving Food Markets and Food Policy in Bangladesh. Baltimore: Johns Hopkins University Press.

Bernard, T., D. J. Spielman, A. S. Taffesse, and E. Z. Gabre-Madhin. 2010. Cooperatives for Staple Crop Marketing. Research Monograph 164. Washington, DC: International Food Policy Research Institute.

Cody, D., P. Dorosh, and B. Minten. 2009. "Evaluating Alternative Policy Responses to Higher World Food Prices: The Case of Increasing Rice Prices in Madagascar." American Journal of Agricultural Economics 91 (3): 711-722.

Dercon, S., R. V. Hill, and A. Zeitlin. 2009. "In Search of a Strategy: Rethinking Agriculture-Led Growth in Ethiopia." Synthesis Paper prepared as part of a study on agriculture and growth in Ethiopia. University of Oxford, Oxford, UK. Mimeo. Available at www.economics.ox.ac.uk/members/Stefan.Dercon/In\%20Search\% 20of\%20a\%20Strategy_v3.pdf. 
Dorosh, P. A. 2009. "Price Stabilization, International Trade, and National Cereal Stocks: World Price Shocks and Policy Response in South Asia." Food Security 1 (2): 137-149.

Dorosh, P. A., S. Dradri, and S. Haggblade. 2009. "Regional Trade, Government Policy, and Food Security: Recent Evidence from Zambia." Food Policy 34 (4): 350-366.

Dorosh, P., S. Robinson, and H. Ahmed. 2009. "Economic Implications of Foreign Exchange Rationing in Ethiopia." Ethiopian Journal of Economics 8 (2): 1-31.

Dorosh, P., G. Alemu, A. de Brauw, M. Malek, V. Mueller, E. Schmidt, K. Tafere, and J. Thurlow. 2011. "The Rural-Urban Transformation in Ethiopia.” Ethiopia Strategy Support Program 2 Monograph 1. International Food Policy Research Institute, Addis Ababa, Ethiopia.

Ethiopia, MoFED (Ministry of Finance and Economic Development). 2006. Ethiopia: Building on Progress-A Plan for Accelerated and Sustained Development to End Poverty (PASDEP) (2005/06-2009/10), Vol. 1, Main Text. Addis Ababa, Ethiopia. . 2010. Growth and Transformation Plan: 2010/11-2014/1, Vol. 1, Main Text. Addis Ababa, Ethiopia. Available at www.mofed.gov.et/index.php?option=com content $\&$ view $=$ article $\& i d=14 \&$ Itemid $=94$.

Gilligan, D., J. Hoddinott, and A. S. Taffesse. 2009. "The Impact of Ethiopia's Productive Safety Net Programme and Its Linkages." Journal of Development Studies 45 (10): 1684-1706.

Mellor, J. W., and P. Dorosh. 2010. Agriculture and the Economic Transformation of Ethiopia. Ethiopia Strategy Support Program 2 Discussion Paper 010. Washington, DC: International Food Policy Research Institute.

Rashid, S., A. Gulati, and R. Cummings Jr., eds. 2008. From Parastatals to Private Trade: Lessons from Asian Agriculture. Baltimore: Johns Hopkins University Press.

World Bank. 2006. "Ethiopia: Policies for Pro-Poor Agricultural Growth.” World Bank, Washington, DC. Mimeo.

—. 2010. World Development Indicators 2009 Database. Development Data Group. Washington, DC. 